\title{
Overdraft Lending in Russia: Problems and Ways to Improve
}

\author{
Madina S. Barakhoeva, and Khalid T. Nalgiev* \\ Ingush State University, Republic of Ingushetia, Russia
}

\begin{abstract}
The article discusses one of the types of short-term lendingoverdraft. The problems and prospects for the development of this type of lending are studied, and the procedure for repayment of overdraft lending and market changes is considered. The statistics of overdraft lending of Russian banks is presented.
\end{abstract}

Overdraft lending, as a type of short-term loans, has gained huge popularity in the Russian Federation. The relevance of overdraft lending is that the volume of transactions carried out through bank cards is constantly increasing. Overdraft has a number of advantages in relation to other types of lending, so this type of lending is more attractive to the population. The absence of the need for surety, the speed of providing the service makes overdraft lending more affordable.

First, a few words about overdraft. Overdraft lending is a special type of short-term bank loan. In comparison with other types of loans, overdraft is simple and convenient not only in registration, but also in use. An overdraft loan is provided to cover a temporary lack of funds in circulation on the client's account. The provision of this type of banking service to the population is carried out by debiting funds from the client's bank account in excess of the balance on this account. This operation creates a debit balance in the customer's bank account. At the same time, the agreement between the bank and its client determines the maximum amount of the loan, as well as the conditions for granting and repaying the loan $[1]$.

It should be noted that overdraft involves the elimination of temporary shortages of working capital in enterprises in order to make current payments by lending to the bank's client's current account using the funds of this bank in a total amount of no more than 10$20 \%$ of the monthly turnover on the bank's client's current account ...

The main difference between overdraft and other types of lending is that the overdraft is valid for debit cards. This can be, for example, salary cards or cards that regularly receive funds. Sometimes an overdraft is issued on credit cards, but this is rather an exception to the rule. This was done in order to reduce the risk of non-repayment of the overdraft at the set time [1].

Unlike a traditional loan, which can be issued for several years, and credit card payments can be extended over several months, the overdraft debt is allowed only within a month. During this time, the client is obliged to fully repay the overdraft, otherwise

* Corresponding Author: nalgiev49halid@mail.ru 
additional charges will occur for each day of overdue debt. Later, after paying off the debt, the client can use it again.

The size of the loan or credit limit on a credit card can be several times the average monthly income of the borrower, while the overdraft limit is almost never more than double the regular income.

Repayment of a credit card loan usually occurs gradually, in equal parts, according to the payment schedule. As a result, the repayment of the entire debt can be extended for several months or years. The overdraft repayment system is more strict. The payment is made automatically and in full as soon as the money is credited to the account.

Overdraft fees are usually higher than on credit cards. But since the overdraft is repaid very quickly, the overpayment is small. Sometimes banks offer an overdraft with a grace period. Thanks to this service, if the borrower repays the debt within a certain period, usually up to 30 days, no interest is charged [5].

Overdraft has more restrictions than other types of loans, but there are also advantages.

Firstly, there is no need to issue an additional card and pay for its service. You can use your own salary card.

Secondly, the overdraft is issued once, and you can use it an unlimited number of times during the year or until the card expires. It should be noted that the term of using the overdraft also depends on the conditions of the bank.

Thirdly, the system of automatic repayment of the provided overdraft allows the client not to worry about repaying the debt to the bank on time. The overdraft is debited as soon as the salary or other payment is credited to the account.

Thus, we can say with confidence that overdraft lending is a good opportunity for those people who urgently need funds at a certain time. In these situations, overdraft lending is the best option for consumers [2].

In the lending market in Russia, many banks provide their customers with overdraft services. This service is provided primarily on debit cards. The conclusion of an overdraft loan agreement can be for a period of up to 1 year, depending on the financial situation of the borrower.

Having studied the data from the official websites of the largest commercial banks of the Russian Federation, we note that the repayment of the client's debt on overdraft lending occurs in one of the following two ways:

- Full monthly repayment of the client's debt. The loan account is "reset" to zero within the period from 30 to 90 calendar days from the date of debt formation, depending on the financial condition of the borrower;

- Tranche repayment of the client's debt. The payment of each tranche issued to the client occurs within 30-90 calendar days after the date of issue. This type of repayment is also applied depending on the financial position of the borrower.

At present, with the onset of the economic crisis in the country, people began to believe that the usual overdraft banking service, which is quite profitable and simple for the consumer, is economically unprofitable for Russian banks. It was thought that overdraft lending would disappear from the line of banking products. These concerns were not unfounded. Over the past 2020, the global situation has had a negative impact on the Russian banking system: the requirements for borrowers have tightened, banks have begun to more carefully assess the solvency of the borrower. As the Equifax credit bureau notes in its study, in 2020, banks issued 8 times fewer cards to Russians with an overdraft option, that is, with the possibility of overspending funds on the account, than last year - 2800 against 22300 .

Table 1 presents statistics on the volume of overdraft lending by popular commercial banks in Russia [3]. 
Table 1. Overdraft lending in Russia, BLN RUB

\begin{tabular}{|l|l|l|l|l|}
\hline № & $\begin{array}{l}\text { Ranking } \\
\text { Position }\end{array}$ & Name of Bank & $\begin{array}{l}\text { Lending volume as } \\
\text { of January 1,2020 }\end{array}$ & $\begin{array}{l}\text { Volume of lending as } \\
\text { of January 1,2021 }\end{array}$ \\
\hline 1 & 1 & Sberbank of Russia & 117,2 & 91,2 \\
\hline 2 & 2 & Bank VTB 24 & 30,03 & 29,7 \\
\hline 3 & 6 & Gazprom Bank & 7,3 & 4,5 \\
\hline 4 & 3 & Alfa-Bank & 27,7 & 21,5 \\
\hline 5 & 7 & Rosbank & 5,9 & 6,3 \\
\hline
\end{tabular}

After analyzing the statistical data, we can talk about a significant decrease in the volume of overdraft lending. The reasons for such changes, in our opinion, are as follows. The first reason is the situation with the Covid-19 coronavirus infection. Considering that during the period of self-isolation the number of new employees hired by various organizations fell significantly, the decrease in the volume of overdrafts issued looks quite logical. The second reason is the disadvantages of overdraft lending, such as the absence or shortened grace period, a smaller limit, and a link to a current account. In the near future, this trend may well lead to a complete rejection of this product.

Having studied the experience of foreign banks, we came to the conclusion that there are some features of overdraft lending that are advisable to implement in Russian banks. For example, the experience of British banks is very interesting. When deciding on the possibility of lending, they take into account the following principles:

- the overdraft cannot be provided if the source of its repayment is not determined;

- $\quad$ overdraft is provided only to identified and eligible clients;

- the security of the transaction and the source of repayment of the loan should not in any way affect the reputation of the bank;

- determination of the loan price should be made in accordance with the level of risk and the used valuation model;

- implementation of collateral on the loan should be secondary and not the main source of repayment of the loan;

- the loan provided must comply with the business strategy developed by the borrower;

- $\quad$ application of an individual approach to the client;

- $\quad$ the bank must be able to trace the use of the loan;

- the price of medium-term and long-term credit transactions, their structure and collateral should be such that the bank could sell the loan to a third party if necessary;

- additional precautions should be taken if credit is granted to enterprises entering a new market, producing new products;

- all clients should be assigned managers responsible for monitoring the performance of the enterprise based on accounting data;

- a loan should not be provided to a client who expects to repay it only in the event of a successful combination of events;

- $\quad$ it is necessary to avoid a disproportionately large amount of risk per borrower and concentration of risks of a certain category of borrowers;

- market risks and risks of certain groups of borrowers should be covered by the liabilities of persons who are creditworthy enough to pay off these liabilities;

- $\quad$ credit services are provided only if all risks are within the permissible limits;

- borrowers must provide regular and complete information regarding their activities and financial situation. 
The overdraft limit, in our opinion, should be differentiated depending on the aggregate average monthly credit turnover for the borrower's settlement / current account and depending on the type of collateral.

To date, most commercial banks set uniform overdraft lending terms for all clients. We believe that this is unreasonable, since the actual period of using the overdraft by borrowers is different due to the peculiarities of the organization of settlements. Thus, we propose to establish an individual term for using this type of loan [4].

For certain categories of borrowers, we propose to introduce a system for issuing an overdraft loan on favorable terms. Separate categories of borrowers include borrowers who have a positive credit history with the bank. By favorable terms, we mean the following: an increased overdraft limit, an unlimited period of using this service, a minimum interest rate and other conditions that will make overdraft lending profitable for a client. Among the main requirements that may be imposed on the borrower when granting a loan, the following can be noted:

- availability of permanent registration and residence in the territory served by the bank;

- $\quad$ availability of the main place of work in the territory served by the bank;

- the presence of continuous work experience of at least six months.

Summing up, we note that an overdraft loan is an independent type of bank loan that covers the deficit of funds, which is formed as a result of short-term aggregate needs of the borrower for additional working capital. Due to special risks, this loan is issued to credible and reliable clients. Its consumers are mainly large enterprises that meet certain requirements of the bank. Among these requirements is a fairly powerful cash flow, the credit part of which can guarantee the repayment of the loan. An overdraft loan is multipurpose in nature and creates a number of advantages for both the bank and the borrower.

\section{References}

1.M.S. Barakhoeva, Kh.T. Nalgiev, Development of the organization and methods of accounting for lending operations to legal entities by commercial banks // Actual problems of the humanities and natural sciences. - 4, 23-26. ISSN: 2073-0071, (2020)

2. M.S. Barakhoeva, Methodological aspects of organizing and accounting for overdraft transactions, -7th International Scientific and Practical Conference "Theory and Practice of Modern Science", pp.107-113, 08-09 April 2015,Moscow (2015)

3. Portal of banking analyst. Instrument of a banking analyst, a client of a bank for the analysis of the financial condition and reliability of banks. Retrieved from: https://analizbankov.ru/rating.php?PokId=4587

4. Directory 24. Overdraft: problems and development prospects. Retrieved from: https://spravochnick.ru/bankovskoe_delo/overdraft_problemy_i_perspektivy_razvitiya/

5. T.O. Dobrikova, Overdraft as a form of short-term lending, International scientific research: - 26th International Scientific and Practical Conference,pp.181-183, Publishing House Scientific Center "Olymp", Moscow(2017) 